\title{
Concentrations, hydrochemistry and risk evaluation of selected heavy metals along the Jimi River and its tributaries at Obuasi a mining enclave in Ghana
}

Noah Kyame Asare-Donkor*, Edward Ebow Kwaansa-Ansah, Francis Opoku and Anthony Apeke Adimado

\begin{abstract}
Background: Surface water represents significant source of fresh water for irrigation and drinking purposes and therefore preserving the availability and quality of this resource is extremely important. Surface water samples within the catchment area of the Obuasi mine were analysed to assess dissolved concentrations, hydrochemistry, risk evaluation of selected metals and their effects on drinking water quality. Water samples were collected from the Jimi River and its tributaries and analysed for physico-chemical parameters and heavy metals using standard analytical methods. Health risk assessment of $\mathrm{As}, \mathrm{Pb}, \mathrm{Fe}, \mathrm{Cd}, \mathrm{Ni}$ and $\mathrm{Zn}$ based on the average daily dose, hazard quotient and cancer risk was also determined.

Results: The results indicated that, most of the physico-chemical parameters are within WHO guidelines except conductivity, turbidity, alkalinity and total hardness. The mean concentrations of heavy metals and ionic dominance pattern follow the order: $\mathrm{Cd}<\mathrm{As}<\mathrm{Pb}<\mathrm{Zn}<\mathrm{Ni}<\mathrm{Fe}, \mathrm{Ca}^{2+}>\mathrm{Mg}^{2+}>\mathrm{K}^{+}>\mathrm{Na}^{+}$and $\mathrm{HCO}_{3}{ }^{-}>\mathrm{SO}_{4}{ }^{2+}>\mathrm{Cl}^{-}$. The healthrisk assessment revealed that hazard quotient $\left(\mathrm{HQ}_{\text {ing }}\right)$ and hazard index $\left(\mathrm{H}_{\text {ing }}\right)$ values were below the acceptable limit, indicating non-carcinogenic risk to the recipient via oral intake and dermal contact of the water. The calculated values for chronical daily intake (CDI) were found in the order of $\mathrm{Fe}>\mathrm{Zn}>\mathrm{As}>\mathrm{Pb}>\mathrm{Cd}>\mathrm{Ni}$ in both adults and children. The carcinogenic risk ( $\mathrm{CR}_{\text {ing }}$ ) via ingestion route for $\mathrm{As}, \mathrm{Cd}$, and $\mathrm{Pb}$ were higher than the acceptable limit $\left(10^{-6}\right)$. Multivariate statistical analysis results revealed that natural processes and anthropogenic activities were the main sources of water contamination.
\end{abstract}

Conclusions: The results suggested multiple natural processes and anthropogenic activities like mining significantly contribute to the considerable environmental pollution contamination of the Jimi River and its tributaries. Our findings have important public health implications, and we suggest that a system of sentinel surveillance is being implemented that, in turn, can guide adequate responses.

Keywords: Mining, Surface water, Heavy metals, Health risk assessment, Hydrochemistry, Jimi River

\section{Background}

Mining is one of the most important economic activities which have the potential of contributing substantially to the development of economies of countries endowed with the mineral resources all over the world. Ghana is

*Correspondence: asaredonkor@yahoo.co.uk

Department of Chemistry, Kwame Nkrumah University of Science and Technology, Kumasi, Ghana not exempted from the world water crisis which is affecting other countries in many parts of the world. The assessment of surface water quality status is important for socio-economic growth and development (Ishaku 2011). Water is essential to life and safe drinking water reduces the burden of infection and increases life expectancy (American Water Works Association 1953). Surface water is the foremost source of drinking water in many rural areas in Ghana for many decades, it plays an

\section{Springer}


important role in the socio economic development of the country (Yankey et al. 2011). Jimi River in Obuasi Municipality provides portable water for a wide range of domestic activities and the river is prone to contamination/ pollution from mining activities, industrial, agricultural and domestic sources. These wastes which are of various types can affect the occurrence, composition as well as the distribution of many aquatic species, depending on their levels of tolerance and adaptability. Parameters for drinking water quality typically fall under two categories: chemical/physical and microbiological (Ackah et al. 2011; Sayyed and Wagh 2011; Tiwari 2011).

In Ghana, contaminations of surface and ground water bodies have particularly been prevalent in gold mining communities (Davis et al. 1994; Kuma 2004; Manu et al. 2004; Kuma and Younger 2004; Obiri 2007). Gold mining has played a significant role in the socio economic life of Ghana for the past years (Akabzaa et al. 2007). Activities associated with mining and mineral processing operations have significant potential to pollute both surface and groundwater either directly or indirectly. Mining by its nature has been known to consume and divert water and can seriously pollute water resources (Miller 1999). These activities always disrupt the surface and in turn affects soils, surface water and near-surface ground water, fauna, flora and all alternative types of land-use (Fuggle and Rabie 1994). Water and soil contamination caused by acid mine drainage (AMD) is a significant environmental problem in some parts of the world, particularly in densely populated developing countries where human habitats are usually in close proximity to mine sites (Lee 2003). More recently concerns have been raised about the stability and environmental performance of tailings dams and impoundments (Aucamp and van Schalkwyk 2003). Inactive tailings impoundments also have received attention due to the long-term effects of windblown dispersal, groundwater contamination, and acid drainage (USEPA 1994; Aucamp and van Schalkwyk 2003).

In the Obuasi mining area, large deposits of mine wastes, ore stockpiles and waste rocks have become a heap around the extraction plants. Weathering of the heaped waste materials such as mercury, arsenic, lead and cadmium among others result in the release of toxic chemicals into the environment especially, into water bodies. Heavy metal pollution within some mining communities of Ghana has been widely studied (Adimado and Amegbey 2003; Akabzaa et al. 2007; Carboo and Serfor-Armah 1997; Essumang et al. 2007; Hilson 2002; Manu et al. 2004; Obiri 2007; Yidana et al. 2007; Amasa 1975; Bamford et al. 1990; Golow et al. 1995; Anglogold Ashanti 2005). Amonoo-Neizer et al. (1995) found significant distribution of As and $\mathrm{Hg}$ in the top soils, plantain, water fern, elephant grass, cassava and mud fish at Obuasi and its environs. So far, it appears that arsenic constitutes the major trace element problem in the Obuasi area (Amonoo-Neizer et al. 1995; Asiam 1996; Smedley 1996; Smedley et al. 1996; Ahmad and Carboo 2000; Kumi-Boateng 2007). Most of these studies had involved the establishment of the levels and distribution of these toxic elements in the environment in relation to established guideline values but had not gone further to assess the life cycle toxicity of these environmental releases from mineral extraction and processing.

Access to clean drinking water, which is a basic human right, is essential for good human health, increased productivity and enhanced economic development. Gold mining activities coupled with population growth and other anthropogenic activities have the tendency to impact negatively on the quality of surface water within the Obuasi Municipality and its environs. The deterioration the quality of these surface water resources are influenced by the characteristics of the media through which the water passes on its way to the surface water zone of saturation. Though the presence of some heavy metals in the living systems in trace amount is important for normal development (Kori-Siakpere and Ubogu 2008), others are completely toxic and need to be monitored continuously. These metals are capable of bioaccumulation and bio-magnification, resulting to morbidity and often mortality in living organisms (Ayotunde et al. 2011; Ada et al. 2012). There is thus the need for the assessment of the drinking water quality within the Obuasi mine area and its environs to ascertain the quality of surrounding water bodies and the safety of the inhabitants. The objective of this study is to determine the physicochemical parameters and levels of some trace metals around the Jimi River and its tributaries in the Obuasi a mining enclave in the Ashanti Region of Ghana and compare with literature values and International guideline limits. The choice of selected parameters for the analysis was based on the intended use of the water from these sources (domestic and agricultural), toxicity of the metals and geology/mineralogy of the area. In addition, an unbiased multivariate technique and linear stoichiometric plot were applied to the hydrochemical data set to identify the various chemical processes that influence the surface water quality. Finally health risk assessment through oral ingestion and dermal absorption through skin exposures contact of the toxic elements in the water was evaluated.

\section{Methods}

\section{Study area}

Obuasi is located between latitude 5.35 and $5.65 \mathrm{~N}$ and longitude 6.35 and $6.90 \mathrm{~N}$ (Fig. 1). It covers a land area of $162.4 \mathrm{~km}^{2}$. There are 53 Communities in the Obuasi 


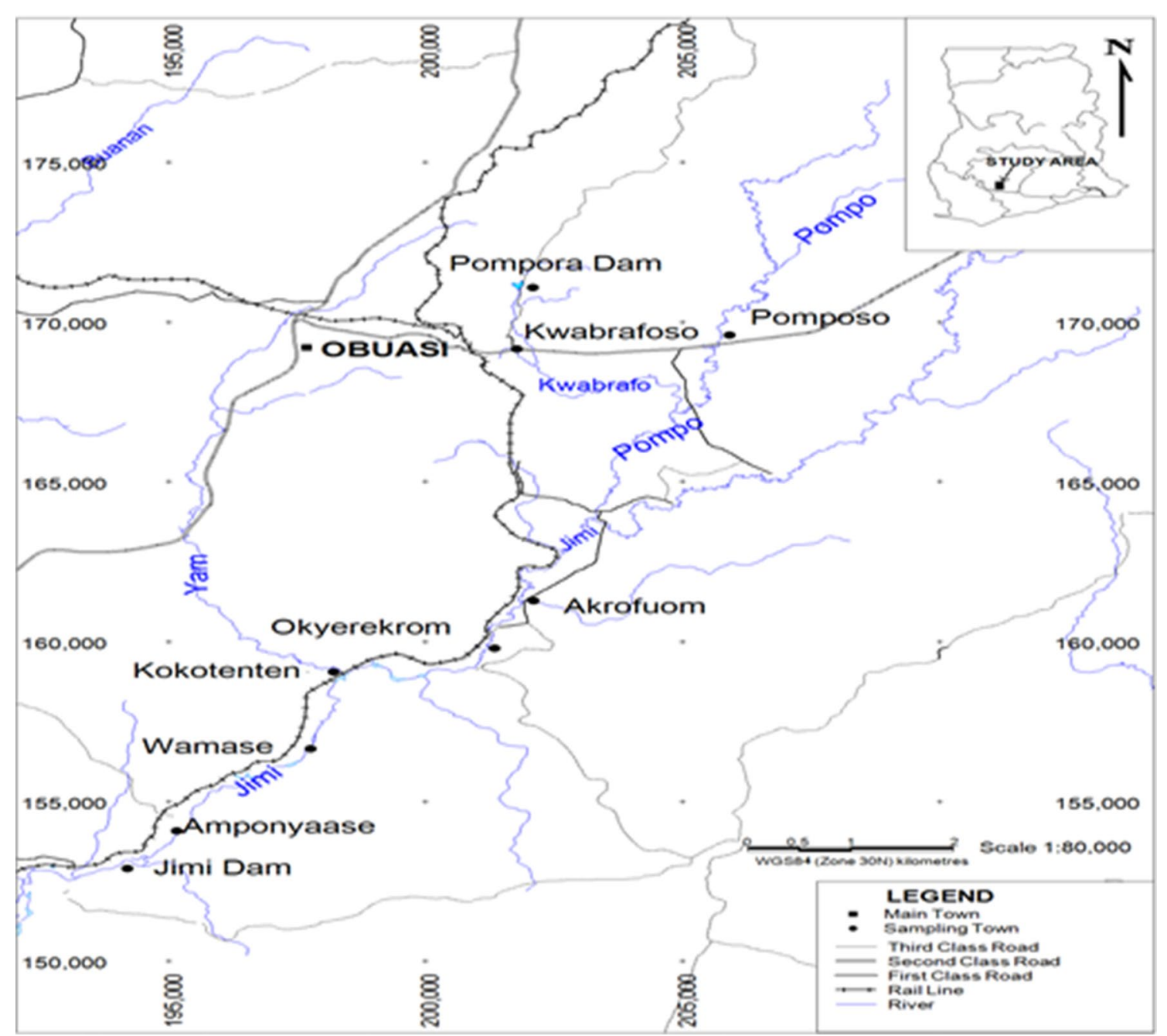

Fig. 1 Obuasi and its environs showing the Jimi River and its tributaries where sampling was done.

Municipality. The Municipality is located in the southern part of the Ashanti Region and has undulating topography. The climate is of the semi equatorial type with a double rainfall regime. The mean annual rainfall ranges between 125 and $175 \mathrm{~mm}$ whilst average annual temperature is $25.5^{\circ} \mathrm{C}$ and relative humidity ranges between 75 and $80 \%$ in the wet season. Rocks in the Municipality are mostly of Tarkwaian (Pre-Cambrian) and Upper Birimian formation which are noted for their rich mineral bearing potentials. Areas around the contacts of the Birimian and Tarkwaian zones known as reefs are noted for gold deposits.

\section{Sampling and sample treatment}

Water samples were collected into 1-L plastic bottles, which had been adequately washed with detergents, rinsed several times with de-ionised water and conditioned. A total of sixty-seven (67) samples were obtained from Akrofuom (AK), Okyerekrom (OK), Wamasi (WA), Kokotenten (KKT), and Amponyase (AM), the Pompora Pump Station (PPS), Kwabrafo River (KAA), and the Jimi Dam (JM) within the concession of AngloGold Ashanti Limited. The raw water sample was collected from various towns along the Jimi dam. In each of the sampling points the raw water was collected at the banks and the middle of the lake (across the lake profile) and mixed in a pre-washed $300 \mathrm{~mL}$ plastic sample bottom. The samples for heavy metal analysis were treated immediately on site with Nitric acid $\left(\mathrm{HNO}_{3}\right)$ at $\mathrm{pH}$ of 2 to preserve them before transportation to the laboratory for analyses. The water samples were immediately placed in an ice packs and transported to the laboratory till the time of analysis. 


\section{Sample analysis}

\section{Analysis of physico-chemical parameters}

A PC 300 Waterproof Handheld pH/Conductivity/TDS/ Temperature meters was used for temperature, $\mathrm{pH}$, TDS and EC analyses. Total suspended solids (TSS) was analysed by filtering a $100 \mathrm{~mL}$ volume of a well-mixed water sample through a weighed standard glass-fibre filter. The residue retained on the filter was then dried in an oven at $103-105^{\circ} \mathrm{C}$ for $1 \mathrm{~h}$. It was then cooled in desiccators and weighed. The increase in weight of the filter represented the total suspended solids based on the conventional calculations. Turbidity was determined using Hach model 2100P turbidity meter.

The anions and cations were analysed by Metrohm 861 Advanced Compact IC Ion Chromatograph with the appropriate column (Polyvinyl alcohol with quaternary $\left.\mathrm{NH}_{4}{ }^{+}\right)$and eluent $\left(\mathrm{NaHCO}_{3}{ }^{-} / \mathrm{Na}_{2} \mathrm{CO}_{3}\right)$. The water samples were analysed for $\mathrm{NO}_{2}{ }^{-}, \mathrm{NO}_{3}{ }^{-}, \mathrm{S}_{2}{ }^{-}, \mathrm{SO}_{4}^{2}, \mathrm{CN}^{-}$ anions using $\left(\mathrm{NaHCO}_{3}{ }^{-} / \mathrm{Na}_{2} \mathrm{CO}_{3}\right)$ eluent after the appropriate calibration curves had been obtained. Similarly $\mathrm{Na}^{+}, \mathrm{K}^{+}, \mathrm{Ca}^{2+}$ and $\mathrm{Mg}^{2+}$ cations in the water samples were analysed using nitric acid as eluent after appropriate calibration curves had been obtained.

\section{Digestion procedure for heavy metal analysis}

The water samples were digested using concentrated Analar nitric acid according to Zhang (2007). Briefly $100 \mathrm{~mL}$ of each sample was measured and transferred into a $250 \mathrm{~mL}$ beaker, $5 \mathrm{~mL}$ of concentrated $\mathrm{HNO}_{3(\mathrm{aq})}$ (Analar, 98\%) was added. The mixture was gently heated on a hot plate after adding few boiling chips, and evaporated down to about $20 \mathrm{~mL}$. Another $5 \mathrm{~mL}$ of the concentrated $\mathrm{HNO}_{3}$ was added and then heated for another $10 \mathrm{~min}$ and allowed to cool. About $5 \mathrm{~mL}$ of $\mathrm{HNO}_{3}$ was used to rinse the sides of the beaker, the solution was quantitatively transferred into a $100 \mathrm{~mL}$ volumetric flask and made up to the mark with distilled water.

\section{Heavy metal analysis}

The UNICAM 969 atomic absorption spectrophotometer (AAS) which uses air acetylene flame was used to analyse $\mathrm{Pb}, \mathrm{Fe}, \mathrm{Cd}, \mathrm{Ni}$, and $\mathrm{Zn}$. by choosing the appropriate wavelengths of the various elements. Standard curves were obtained by running prepared a standard solutions of the various metals. The absorbance values of the metals present in the water samples were determined and by comparing with the standard absorbance of the various heavy metals, the concentrations were determined. This was repeated three times for each sample and the mean concentration was taken as the actual level of concentration of the heavy metal in $\mathrm{mg} / \mathrm{L}$. Background corrections were activated in the analysis of $\mathrm{Pb}$. Quality of the analysis was ensured through replicate analysis, analysis of blank, pre-digestion spikes and analysis of certified reference materials.

\section{Health risk assessment for some selected metals}

Human beings may be exposed to metals through three main routes including direct ingestion, inhalation through mouth and nose, and dermal absorption through skin exposures; ingestion and dermal absorption are common for water exposure (USEPA 1989, 2005; Wu et al. 2009). The expressions for human health risk assessment were obtained from the USEPA Risk Assessment Guidance for Superfund (RAGS) methodology (USEPA 1989). The relation for the calculation is given by Eqs. (1) and (2).

$$
\begin{gathered}
D_{\text {ing }}=\frac{C \text { water } \times I R \times E F \times E D}{B W \times A T} \\
D_{\text {derm }}=\frac{C \text { water } \times S A \times K P \times E T \times E F \times E D \times C F}{B W \times A T}
\end{gathered}
$$

where $D_{\text {ing }}$ is exposure dose through ingestion of water ( $\mu \mathrm{g} / \mathrm{kg} /$ day); $D_{\text {derm }}$ is exposure dose through dermal absorption $(\mu \mathrm{g} / \mathrm{kg} /$ day); Cwater is concentration of the estimated metals in surface water $(\mu \mathrm{g} / \mathrm{L}) ; \mathrm{IR}$ is ingestion rate (L/day); EF is exposure frequency (days/year); ED is exposure duration (years); BW is average body weight $(\mathrm{kg}) ; \mathrm{AT}$ is averaging time (days); SA is exposed skin area $\left(\mathrm{cm}^{2}\right)$; ET is exposure time (h/day); CF is unit conversion factor $\left(\mathrm{L} / \mathrm{cm}^{3}\right)$; and $K P$ is dermal permeability coefficient $(\mathrm{cm} / \mathrm{h})$.

Potential non-carcinogenic risks for exposure to contaminants were assessed by comparison of the calculated contaminant exposures from each exposure route with the reference dose ( $\mathrm{RDD})$ in order to produce the hazard quotient (HQ), defined by Eq. (3) (USEPA 1989).

$$
\mathrm{HQ}_{\text {ing/derm }}=\frac{D_{\text {ing } / \text { derm }}}{R f D_{\text {ing } / \text { derm }}}
$$

where $\mathrm{HQ}_{\text {ing/derm }}$ is hazard quotient via ingestion or dermal contact (unitless) and $\operatorname{Rf} D_{\text {ing/derm }}$ is oral/dermal reference dose ( $\mu \mathrm{g} / \mathrm{kg}$-day). The $\operatorname{Rf} D_{\text {ing }}$ and $\operatorname{Rf} D_{\text {derm }}$ values were obtained from the literature elsewhere $\mathrm{Zn}$ ( $\mathrm{Li}$ and Zhang 2010; USEPA 1989; Wu et al. 2009; Liang et al. 2011).

The hazard quotient (HQ) is a numeric estimate of the systemic toxicity potential posed by a single element within a single route of exposure. The overall potential for non-carcinogenic effects posed by more than one element is evaluated by integrating the computed HQs for each element and expressed as a hazard index (HI) as given in Eq. (4) (USEPA 1989)

$$
\mathrm{HI}=\sum_{i=1}^{n} H Q_{i n g / d e r m}
$$


where $\mathrm{HI}_{\text {ing/derm }}$ is hazard index via ingestion or dermal contact (unit less). When $\mathrm{HQ} / \mathrm{HI}$ exceeds unity, there may be a concern for potential human health risks caused by exposure to noncarcinogenic elements (USEPA 1989).

Chronic daily intake (CDI) was evaluated using Eq. (5)

$$
\mathrm{CDI}_{\text {ing }}=\mathrm{C}_{\text {water }} \times \frac{D I}{B W}
$$

where $C_{\text {water }}$, DI and BW represent the concentration of heavy metal in water in $(\mu \mathrm{g} / \mathrm{kg})$, average daily intake of water and body weight respectively. The parameters estimating exposure assessment of metals in water samples used in the study are given in Table 1.

Table 1 Parameters for estimating exposure assessment of metals in water samples used in the study (USEPA 1989, 2005; Wu et al. 2009; Liang et al. 2011)

\begin{tabular}{|c|c|c|c|}
\hline & \multirow[t]{2}{*}{ Unit } & \multicolumn{2}{|l|}{ Values } \\
\hline & & Adults & Children \\
\hline Concentration of metals in water $\left(C_{\text {water }}\right)$ & $\mu g / L$ & & \\
\hline Water injection rate $(\mathrm{IR})$ & L/day & 2.2 & 1.8 \\
\hline Exposure frequency (EF) & Days/year & 350 & 350 \\
\hline Exposure duration (ED) & year & 70 & 6 \\
\hline Average body weight (BW) & $\mathrm{kg}$ & 70 & 15 \\
\hline Average time (AT) & days & 25,550 & 2,190 \\
\hline Exposed skin area (SA) & $\mathrm{Cm}^{2}$ & 18,000 & 6,600 \\
\hline Exposure time (ET) & h/day & 0.58 & 1 \\
\hline Unit conversion factor & $\mathrm{L} / \mathrm{cm}^{3}$ & 0.001 & 0.001 \\
\hline \multicolumn{4}{|l|}{ Dermal permeability coefficient } \\
\hline $\mathrm{Cd}$ & $(\mathrm{cm} / \mathrm{h})$ & 0.001 & \\
\hline $\mathrm{Fe}$ & & 0.001 & \\
\hline $\mathrm{Ni}$ & & 0.004 & \\
\hline As & & 0.001 & \\
\hline $\mathrm{Zn}$ & & 0.006 & \\
\hline $\mathrm{Pb}$ & & 0.004 & \\
\hline
\end{tabular}

Cancer risk (CR) was also evaluated using Eq. (6).

$$
\mathrm{CR}_{\text {ing }}=\frac{D_{\text {ing }}}{S F_{\text {ing }}}
$$

where $\mathrm{SF}_{\text {ing }}$ is the cancer slop factor. The $\mathrm{SF}_{\text {ing }}$ for As is $1.5 \times 10^{3} \mathrm{Cd}$ is $6.1 \times 10^{3}$ and $\mathrm{Pb}$ is $8.5 \mu \mathrm{g} / \mathrm{g} /$ day (USEPA 1989, 2005; Yu et al. 2010).

\section{Statistical analysis}

Analytical data were processed using IBM SPSS version 20 software. Basic statistics such as mean was computed and multivariate analyses performed on the corresponding variables. Principal component analyses (PCA) was used to identify the possible heavy metal sources. PCA was performed by the Ward's method was used to extract data and the linkage distance of similarity was calculated by the squared Euclidean distances.

\section{Results and discussion}

Physico-chemical parameters

Table 2 summarizes the physico-chemical parameters of the water samples along the Jimi River and its tributaries.

The colour of the water samples from all the sampling sites were above the WHO limit of $15 \mathrm{~Hz}$. The highest colour of 2,930.31 $\pm 18 \mathrm{~Hz}$ was measured in the samples from PPS. The high colour measured may be due to dissolved components such as iron and manganese, humus, plankton, weeds and or industrial wastes.

Jimi River and its tributaries largely exhibited slightly alkaline $\mathrm{pH}$ values which were within the WHO limit of 6.5-8.5. Though the selection of raw water as a drinking water source is never based solely on $\mathrm{pH}$, these results show that no significant adverse health effects, due to toxicity of dissolved metal ions and protonated species were expected. In addition no aesthetic effects (e.g. taste), were also expected. It was however slightly above the natural background level of 7.0. This increase in $\mathrm{pH}$

\begin{tabular}{|c|c|c|c|c|c|c|c|c|}
\hline Code & $\mathrm{pH}$ & $\begin{array}{l}\text { Conductivity } \\
(\mu \mathrm{S} / \mathrm{cm})\end{array}$ & Turbidity (NTU) & $\begin{array}{l}\text { Alkalinity } \\
\text { as } \mathrm{CaCO}_{3}(\mathrm{mg} / \mathrm{L})\end{array}$ & $\begin{array}{l}\text { Total hardness } \\
\text { (mg/L) }\end{array}$ & $\begin{array}{l}\text { Calcium hard- } \\
\text { ness (mg/L) }\end{array}$ & $\begin{array}{l}\text { Magnesium } \\
\text { hardness (mg/L) }\end{array}$ & Colour (Hz) \\
\hline AK & $7.29 \pm 0.065$ & $305.00 \pm 17.0$ & $10.585 \pm 0.04$ & $73.00 \pm 10.35$ & $72.24 \pm 8.84$ & $63.00 \pm 8.0$ & $9.60 \pm 1.20$ & $121.84 \pm 0.69$ \\
\hline $\mathrm{AM}$ & $7.29 \pm 0.05$ & $277 \pm 13$ & $103.5 \pm 0.50$ & $101.50 \pm 6.50$ & $65.24 \pm 0.84$ & $56.00 \pm 4.20$ & $9.24 \pm 0.84$ & $1,154.23 \pm 34.23$ \\
\hline JMC & $7.25 \pm 0.03$ & $60.00 \pm 1.0$ & $3.50 \pm 0.01$ & $52 \pm 2.30$ & $15.36 \pm 0.08$ & $12 \pm 1.0$ & $3.36 \pm 0.16$ & $40.38 \pm 0.8$ \\
\hline KAAC & $7.25 \pm 0.02$ & $1,902.00 \pm 11$ & $3.04 \pm 0.43$ & $285 \pm 6.4$ & $854.96 \pm 11.1$ & $776 \pm 7.1$ & $78.96 \pm 1.42$ & $35.08 \pm 0.6$ \\
\hline KK & $7.32 \pm 0.81$ & $503.00 \pm 0.01$ & $17.85 \pm 0.01$ & $121 \pm 3.10$ & $122.32 \pm 5.8$ & $82 \pm 3.0$ & $40.32 \pm 0.57$ & $205.96 \pm 1.3$ \\
\hline OK & $7.22 \pm 0.51$ & $272.50 \pm 1.50$ & $7.595 \pm 6.75$ & $87.5 \pm 2.50$ & $87.48 \pm 62.44$ & $69.00 \pm 4.0$ & $18.48 \pm 3.44$ & $133.785 \pm 31.56$ \\
\hline PPS & $8.07 \pm 0.91$ & $5.16 \pm 0.8$ & $254.00 \pm 0.01$ & $500 \pm 12.20$ & $1,841.60 \pm 19$ & $1,640 \pm 23$ & $201.60 \pm 4.43$ & $2,930.31 \pm 18$ \\
\hline WA & $7.22 \pm 0.62$ & $124 \pm 9.6$ & $25.5 \pm 5.5$ & $94.0 \pm 9.00$ & $11.36 \pm 5.16$ & $28.0 \pm 5.4$ & $3.36 \pm 0.84$ & $294.23 \pm 94.3$ \\
\hline $\mathrm{WHO}$ & $6.5-8.5$ & $1,500.00$ & 5.00 & 200.00 & 500.00 & N/A & 200.00 & 15.00 \\
\hline
\end{tabular}

Table 2 Mean values of physical parameters for water sampled along the Jimi River and its tributaries 
of the water samples above the normal background levels may be due to the presence of dissolved carbonates and bicarbonates present in the water, which are known to affect $\mathrm{pH}$ of almost all surface water (Chapman 1992). The $\mathrm{pH}$ values in the present study is alkaline than that reported in the Densu Basin (Tay and Kortatsi 2007), Bosomtwi-Atwima-Kwanwoma District (Nkansah and Ephraim 2009) and Tay (2008). pH values lower than 6.5 are considered too acidic for human consumption and can cause health problems such as acidosis which could have adverse effects on the digestive and lymphatic systems of human (Nkansah et al. 2010).

The conductivity values for all the sampling sites fell within the "no effect" range of $1,500 \mu \mathrm{S} / \mathrm{cm}$ for drinking water (WHO 2007) with the exception of sampling sites along the Kwabrafo River. The electrical conductivity of water relates to the total concentration of dissolved ions in water and the temperature at which the measurement is taken. This indicates that no adverse health effects associated with the electrical conductivity of the water were expected. However, since most of the conductivity values were higher than the taste threshold of $45 \mu \mathrm{S} / \mathrm{cm}$, a slight salty taste was expected. The high level of conductivity along the Kwabrafo River may be attributed to the proliferation of local surface mining (Galamsey) activities in the community (USGS 1999). Electrical conductivity is a good measure of dissolved solids; it is an important criterion in determining the suitability of a body of water for irrigation (Kumar and Pal 2012).

The turbidity of the water samples analysed from the Jimi River and its tributaries were found to be above the WHO limit of 5 NTU. Turbidity in water relates to the reduction of transparency due to the presence of particulate matter such as clay or silt, finely divided organic matter, plankton or other microscopic organisms. The high turbidity may be attributed to larger particles such as organic matter and dissolved solids. Schafer et al. (2010) found turbidity in the range of 2-266 NTU in most borehole water throughout Ghana.

Alkalinity values for the water samples were generally below the WHO guideline of $200 \mathrm{mg} / \mathrm{L}$ with the exception of Pompora Pump Station which had $500.12 \pm 12.2 \mathrm{mg} / \mathrm{L}$. According to Chapman (1995), alkalinity levels of $20-200 \mathrm{mg} / \mathrm{L}$ are common in fresh water systems. Waters with high alkalinity values are considered undesirable because of high concentrations of sodium salts and may have a distinctly flat, unpleasant taste (Ramachandra and Solanki 2007). Water with low alkalinity, below $10 \mathrm{mg} / \mathrm{L}$ has little capacity to buffer acidic pollutants and is susceptible to acidification (USEPA 1997).
Total hardness values for all the water samples fell below the WHO guideline of $500 \mathrm{mg} / \mathrm{L}$ with the exception of Kwabrafo River and Pompora Pump Station sampling point which had $854.96 \pm 7.10$ and $1,841.60 \pm 19.0 \mathrm{mg} / \mathrm{L}$, respectively. Absolutely soft waters are tasteless, corrosive and have the property of dissolving metals in solution. Moderately hard water is preferred to soft water for irrigation purposes. The hardness of water is generally due to the presence of calcium and magnesium in the water. Public acceptability of the degree of hardness of water may vary considerably from one community to another depending on local conditions and hardness in excess of $500 \mathrm{mg} / \mathrm{L}$ is tolerable (Putz 2003).

\section{lons and nutrients}

Table 3 summarizes the chemical parameters of the water samples along the Jimi River and its tributaries. The levels of sulphate and sulphide in the water samples were generally low and below the WHO guideline value of 400 and $1.5 \mathrm{mg} / \mathrm{L}$, respectively. High concentration of sulphate in drinking water cause a laxative effect when combined with calcium and magnesium, the two most common ions responsible for water hardness (World Health Organization 2007). Salt water intrusion and acid rock drainage are also sources of sulphate in drinking water. In addition, manmade sources include industrial discharge and deposition from burning of fossil fuel (Okeola et al. 2010).

Nitrate and nitrites levels were found to be below the WHO levels of 50.00 and $5.0 \mathrm{mg} / \mathrm{L}$, respectively. Nitrates $\left(\mathrm{NO}_{3}-\mathrm{N}\right)$ are the final product of the biochemical oxidation of ammonia (Mahananda et al. 2010). The level of Nitrates in water has implication on human health and is an indicator of the degree of organic pollution of the water source (Eletta et al. 2010; Gopalkrushna 2011; Mahananda et al. 2010). High nitrate concentration in drinking water has detrimental effects on pregnant women and babies less than 6 months old (Longe and Balogun 2010). Nitrites occur as an intermediate product of conversion of ammonium ion to nitrate as well as in the nitrification process of ammonia (Eletta et al. 2010). Nitrites $\left(\mathrm{NO}_{2}-\mathrm{N}\right)$ can be more harmful than nitrates in drinking water supply as nitrites can oxidize haemoglobin to methaemoglobin in the body and hinder the transportation of oxygen around the body (Alsabahi et al. 2009; Chapman 1992). The mean levels of ammonia $\left(\mathrm{NH}_{3}-\mathrm{N}\right)$ in Jimi River and its tributaries are lower than the levels of nitrates and nitrites and also fall below the WHO guideline value of $0.5 \mathrm{mg} / \mathrm{L}$. These concentration levels are not alarming and therefore the Jimi River and its tributaries are free from organic pollution. 
Calcium and magnesium levels in the water samples were found to be below the WHO guideline values of 200 and $150 \mathrm{mg} / \mathrm{L}$, respectively. Calcium and magnesium are needed by the body in larger quantities and its lack in human system will lead to adverse health effects. Mean levels of sodium and potassium ions is all the water samples were found to be below the WHO guideline values $200 \mathrm{mg} / \mathrm{L}$ (based on taste) and $0.01 \mathrm{mg} / \mathrm{L}$, respectively.

The chloride levels measured in the water samples were below the WHO limit. The $\mathrm{Cl}^{-}$content in the present study is lower than that of water from Lagos State, Nigeria (2.84-13.47 $\mathrm{mg} / \mathrm{L})$ and Akot, India (290-308 mg/L) (Gopalkrushna 2011; Longe and Balogun 2010). Chloride is one of the major inorganic anion in water and in potable water, the salty taste is produced by the chloride concentrations. Low levels of $\mathrm{Na}^{+}$and $\mathrm{Cl}^{-}$in water sources are an indication of the absence of intrusion of River water (Essumang et al. 2011). There is no known evidence that chlorides constitute any human health hazard and for this reason, chlorides are generally limited to $250 \mathrm{mg} / \mathrm{L}$ in supplies intended for public use (World Health Organization 2007).

Cyanide levels in most of the water samples analysed were found to be extremely higher than the WHO guideline of $0.2 \mathrm{mg} / \mathrm{L}$ except those from sampling sites along the Kwabrafo River where the level was below detection. This calls for a lot of concern because of the health effect of cyanide ingestion and the fact that cyanide can be found in water primarily as a consequence of industrial contamination. Accidental spills of cyanide solutions into rivers and streams have produced massive kills of fish and other aquatic biota (Adimado and Amegbey 2003).

The hydro chemical variables investigated in this study indicated that the major cations are $\mathrm{Ca}$ and $\mathrm{Mg}$ whilst the major anions are $\mathrm{SO}_{4}{ }^{2-}$ and $\mathrm{HCO}_{3}{ }^{-}$as indicated by the whisker and box plot (Fig. 2). The increasing order of the major cations and anions determined from the Whisker and Box plot are $\mathrm{Ca}^{2+}>\mathrm{Mg}^{2+}>\mathrm{K}^{+}>\mathrm{Na}^{+}$and $\mathrm{HCO}_{3}{ }^{-}>\mathrm{SO}_{4}{ }^{2-}>\mathrm{Cl}^{-}$, respectively. The Piper trilinear plot (Fig. 3) of the major cations and anions from the water samples from the Jimi River and its tributaries reveal that they belong to the $\mathrm{Ca}-\mathrm{Mg}$ cation facies and bicarbonate-sulphate facies.

The Schoeller logarithmic diagram (Fig. 4) for the water samples from the Jimi River and its tributaries show that the water is not of one dominant type and may have been influenced by the effects of erosive agents and the accompanying land degradation resulting from mining activities which introduce ions into the water.

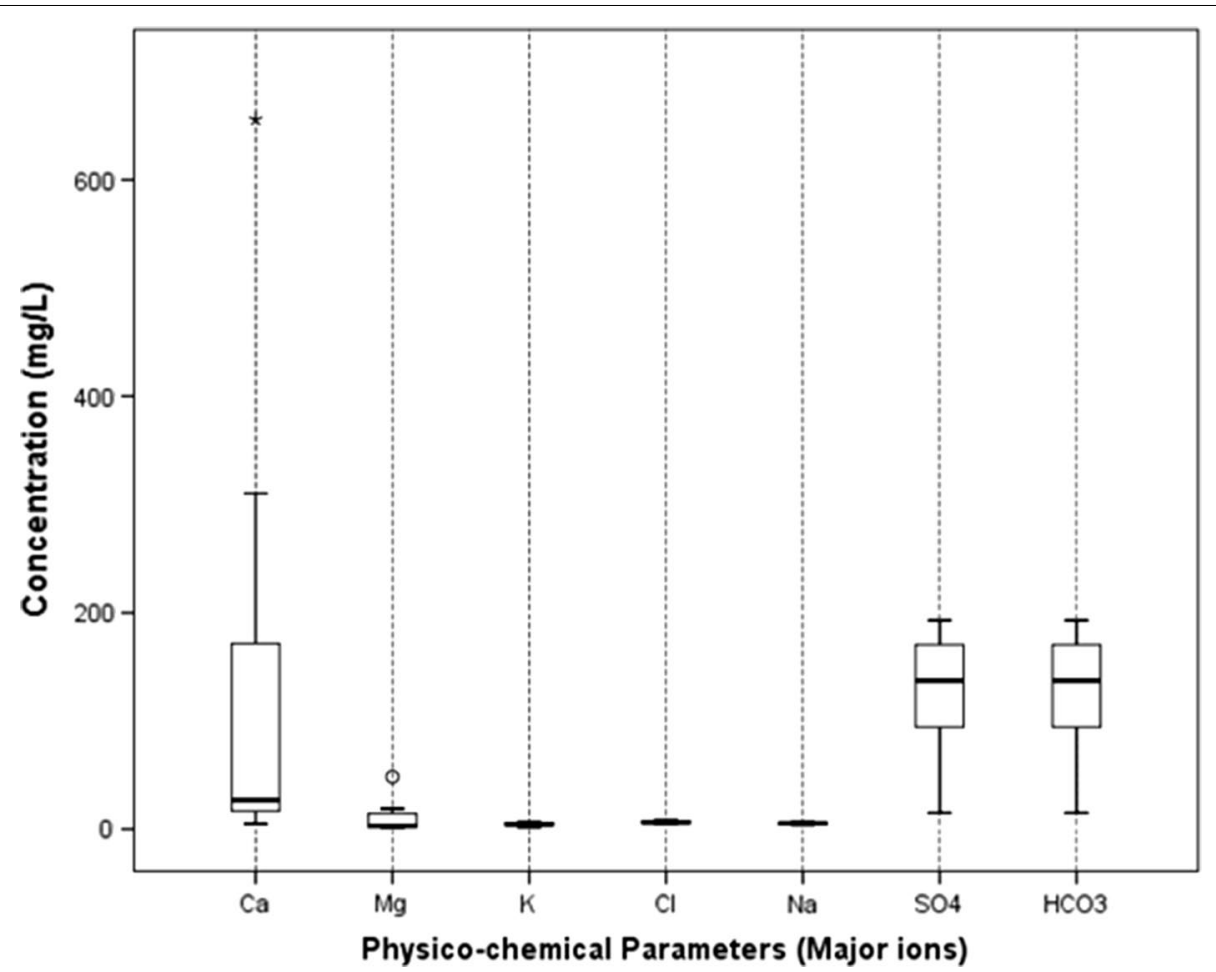

Fig. 2 Box and whisker plot of major ions in water samples form the towns along the Jimi River and its tributaries. The asterisks and white circles represent outliers. The effects of outliers on the outcome of the multivariate analysis were not significant at 95\% confidence limit by Student's $t$ test. 


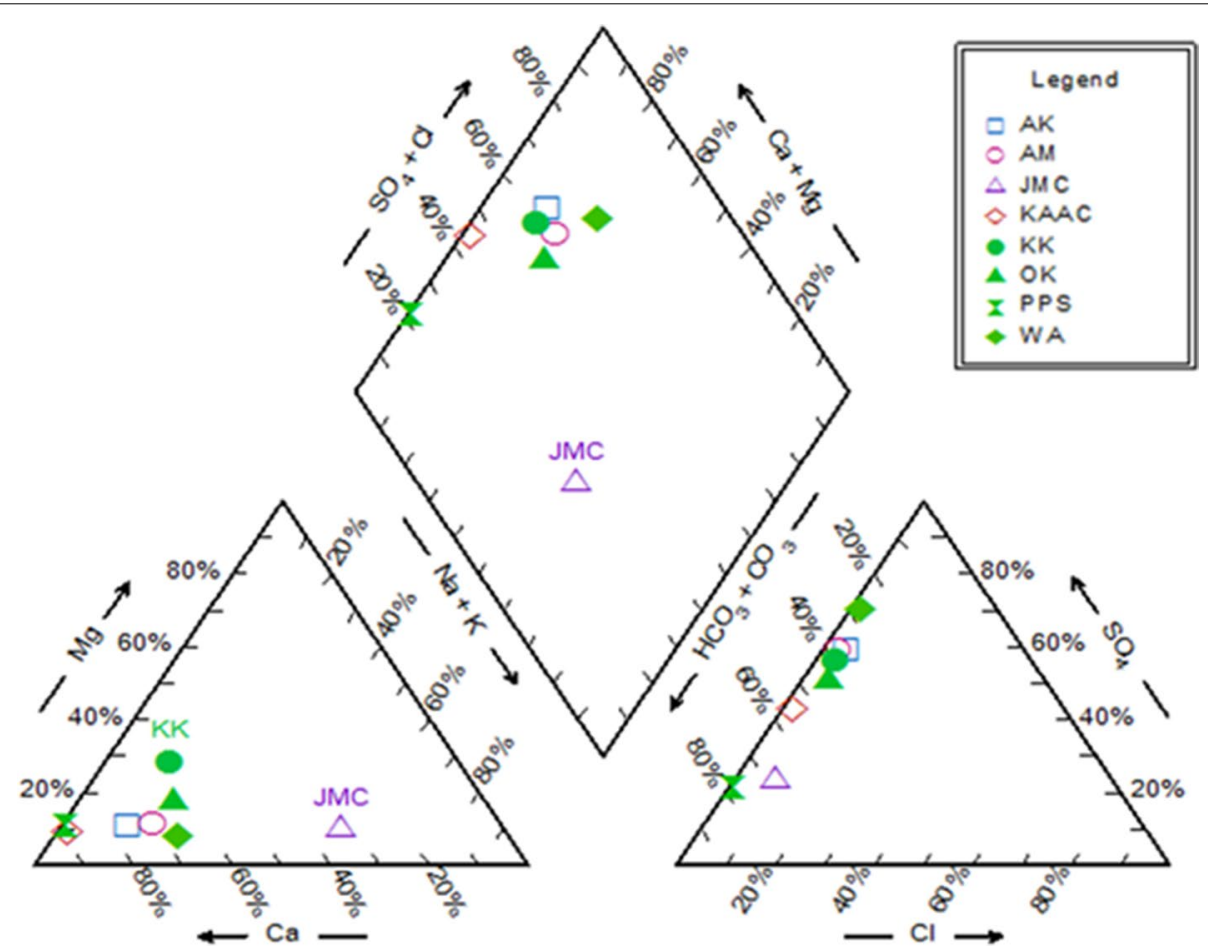

Fig. 3 Piper plots of ions in water samples from the sampling towns along the Jimi River and its tributaries.

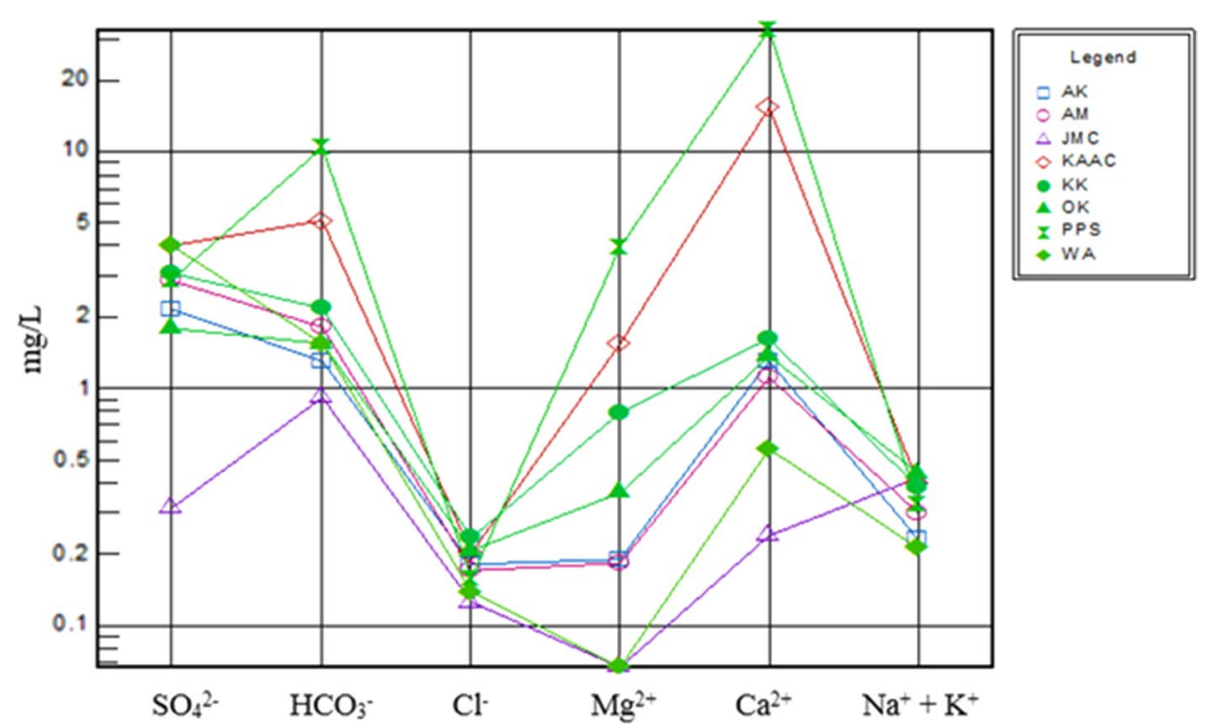

Fig. 4 Schoeller logarithm diagram for ions in water samples from the sampling towns along the Jimi River and its tributaries.

\section{Heavy metals}

Mean trace metal concentration of surface water samples from communities along the Jimi River and its tributaries are given in Table 4. All the water samples had mean Iron levels above the WHO guideline value of $0.03 \mathrm{mg} / \mathrm{L}$ with Kwabrafo River exhibiting an exceedingly high value of $131.06 \pm 0.01 \mathrm{mg} / \mathrm{L}$. This may be as a result of geological formations, acid drainage, runoffs and effluents discharged (EPA 2001). Undesirable effects of high iron consumption can lead to impart of colour and taste 
Table 3 Mean values of chemical parameters for water sampled along the Jimi River and its tributaries

\begin{tabular}{|c|c|c|c|c|c|c|c|c|c|c|c|}
\hline Code & $\mathrm{S}^{2-}(\mathrm{mg} / \mathrm{L})$ & $\mathrm{SO}_{4}{ }^{2-}(\mathrm{mg} / \mathrm{L})$ & $\begin{array}{l}\mathrm{NO}_{3}^{-} \\
(\mathrm{mg} / \mathrm{L})\end{array}$ & $\begin{array}{l}\mathrm{NO}_{2}^{-} \\
(\mathrm{mg} / \mathrm{L})\end{array}$ & $\begin{array}{l}\mathrm{HCO}_{3}^{-} \\
(\mathrm{mg} / \mathrm{L})\end{array}$ & $\begin{array}{l}\mathrm{NH}_{3}-\mathrm{N}^{-} \\
(\mathrm{mg} / \mathrm{L})\end{array}$ & $\begin{array}{l}\mathrm{Mg}^{2+} \\
(\mathrm{mg} / \mathrm{L})\end{array}$ & $\begin{array}{l}\mathrm{Ca}^{2+} \\
(\mathrm{mg} / \mathrm{L})\end{array}$ & $\mathrm{K}^{+}(\mathrm{mg} / \mathrm{L})$ & $\mathrm{Na}^{+}(\mathrm{mg} / \mathrm{L})$ & $\mathrm{Cl}^{-}(\mathrm{mg} / \mathrm{L})$ \\
\hline AK & $0.065 \pm 0.03$ & $103.00 \pm 10.0$ & $0.065 \pm 0.02$ & $20.05 \pm 0.01$ & $89.06 \pm 6.4$ & $0.06 \pm 0.01$ & $2.30 \pm 0.26$ & $26.2 \pm 3.20$ & $2.84 \pm 0.31$ & $3.67 \pm 0.22$ & $6.43 \pm 0.51$ \\
\hline AM & $0.04 \pm 0.01$ & $136.50 \pm 59.5$ & $0.08 \pm 0.01$ & $0.06 \pm 0.01$ & $123.83 \pm 5.50$ & $00.125 \pm 0.065$ & $52.22 \pm 0.20$ & $22.4 \pm 1.62$ & $3.65 \pm 0.14$ & $4.68 \pm 0.21$ & $6.07 \pm 0.33$ \\
\hline$J M C$ & $0.03 \pm 0.01$ & $15.00 \pm 2.01$ & $0.09 \pm 0.02$ & $0.07 \pm 0.03$ & $363.44 \pm 3.6$ & $0.09 \pm 0.01$ & $0.81 \pm 0.04$ & $4.8 \pm 0.40$ & $6.45 \pm 0.28$ & $5.89 \pm 0.33$ & $4.45 \pm 0.24$ \\
\hline KAAC & $0.13 \pm 0.01$ & $193 \pm 5.0$ & $6.60 \pm 1.52$ & $5.10 \pm 0.87$ & $347.70 \pm 9.8$ & $0.20 \pm 0.04$ & $18.95 \pm 0.34$ & $4310 \pm 2.84$ & $4.61 \pm 0.17$ & $6.5 \pm 0.41$ & $7.20 \pm 0.37$ \\
\hline KKT & $0.03 \pm 0.01$ & $148.00 \pm 3.1$ & $0.10 \pm 0.01$ & $0.08 \pm 0.03$ & $3147.62 \pm 4.16$ & $60.06 \pm 0.01$ & $9.68 \pm 0.14$ & $32.8 \pm 1.23$ & $4.55 \pm 0.24$ & $6.09 \pm 0.54$ & $8.28 \pm 0.62$ \\
\hline OK & $0.03 \pm 0.00$ & $86.00 \pm 1.00$ & $0.09 \pm 0.01$ & $0.07 \pm 0.01$ & $106.75 \pm 3.05$ & $50.065 \pm 0.025$ & $54.43 \pm 0.83$ & $27.6 \pm 1.60$ & $6.48 \pm 0.42$ & $6.38 \pm 0.34$ & $7.33 \pm 0.49$ \\
\hline PPS & $0.05 \pm 0.01$ & $138.00 \pm 2.4$ & $0.80 \pm 0.04$ & $b / d$ & $640.00 \pm 11.1$ & $10.19 \pm 0.02$ & $48.38 \pm 1.06$ & $6656 \pm 9.21$ & $4.85 \pm 0.32$ & $4.64 \pm 05$ & $5.60 \pm 0.32$ \\
\hline WA & $0.03 \pm 0.01$ & $193.00 \pm 10.0$ & $0.12 \pm 0.02$ & $0.09 \pm 0.02$ & $2106.75 \pm 3.05$ & $50.13 \pm 0.05$ & $0.81 \pm 0.21$ & $11.2 \pm 2.14$ & $+1.89 \pm 0.21$ & $3.78 \pm 026$ & $4.93 \pm 0.38$ \\
\hline WHO & N/A & 250.00 & 50.00 & 5.00 & $\mathrm{~N} / \mathrm{A}$ & 0.5 & 150.00 & 200.00 & 250 & 250 & 250 \\
\hline
\end{tabular}

$b / d$ below detection limit, N/A not available.

Table 4 Mean trace metal concentration of surface water samples along the Jimi River and its tributaries

\begin{tabular}{llllllll}
\hline Code & $\mathbf{C d}(\mathbf{m g} / \mathbf{L})$ & Fe $(\mathbf{m g} / \mathbf{L})$ & $\mathbf{N i}(\mathbf{m g} / \mathbf{L})$ & $\mathbf{Z n}(\mathbf{m g} / \mathbf{L})$ & $\mathbf{P b}(\mathbf{m g} / \mathbf{L})$ & $\mathbf{C N}^{-}(\mathbf{m g} / \mathbf{L})$ & $\mathbf{A s}(\mathbf{m g} / \mathbf{L})$ \\
\hline AK & $0.02 \pm 0.01$ & $6.095 \pm 0.069$ & $0.045 \pm 0.005$ & $0.365 \pm 0.15$ & $\mathrm{~b} / \mathrm{d}$ & $36.58 \pm 3.97$ & $\mathrm{~b} / \mathrm{d}$ \\
AM & $0.01 \pm 0.01$ & $24.23 \pm 1.53$ & $0.055 \pm 0.095$ & $0.34 \pm 0.12$ & $\mathrm{~b} / \mathrm{d}$ & $46.71 \pm 2.65$ & $\mathrm{~b} / \mathrm{d}$ \\
JMC & $0.03 \pm 0.01$ & $5.94 \pm 0.06$ & $0.01 \pm 0.00$ & $0.46 \pm 0.01$ & $\mathrm{~b} / \mathrm{d}$ & $11.46 \pm 2.02$ & $\mathrm{~b} / \mathrm{d}$ \\
KAAC & $0.01 \pm 0.00$ & $131.06 \pm 7.04$ & $0.35 \pm 0.04$ & $0.88 \pm 0.01$ & $0.29 \pm 0.1$ & $\mathrm{~b} / \mathrm{d}$ & $\mathrm{b} / \mathrm{d}$ \\
KKT & $\mathrm{b} / \mathrm{d}$ & $6.19 \pm 0.72$ & $0.1 \pm 0.00$ & $0.52 \pm 0.01$ & $\mathrm{~b} / \mathrm{d}$ & $17.63 \pm 3.02$ & $\mathrm{~b} / \mathrm{d}$ \\
OK & $0.01 \pm 0.00$ & $10.92 \pm 4.36$ & $0.025 \pm 0.015$ & $0.45 \pm 0.015$ & $\mathrm{~b} / \mathrm{d}$ & $43.18 \pm 0.88$ & $\mathrm{~b} / \mathrm{d}$ \\
PPS & $\mathrm{b} / \mathrm{d}$ & $4.78 \pm 0.04$ & $8.18 \pm 0.01$ & $0.43 \pm 0.01$ & $\mathrm{~b} / \mathrm{d}$ & $33.49 \pm 4.02$ & $0.34 \pm 0.00$ \\
WA & $0.01 \pm 0.00$ & $12.13 \pm 2.02$ & $0.03 \pm 0.01$ & $0.44 \pm 0.01$ & $\mathrm{~b} / \mathrm{d}$ & $53.76 \pm 8.03$ & $0.07 \pm 0.00$ \\
WHO & 0.005 & 0.3 & 0.02 & 5.0 & 0.01 & 0.07 & 0.01 \\
\hline
\end{tabular}

$b / d$ below detection limit, N/A not available.

in water bodies, the staining of plumbing laundry and stimulating the growth of iron bacteria (Agarwal 1999; ATSDR 1993). Previous studies had shown maximum levels in groundwater to be $18.3 \mathrm{mg} / \mathrm{L}$ and maximum levels in surface water to be $4.01 \mathrm{mg} / \mathrm{L}$ (Kuma 2004).

The levels of lead in most of the water samples were below the WHO limit of $0.01 \mathrm{mg} / \mathrm{L}$ with the exception of sampling sites along the Kwabrafo River which had an exceedingly high mean value of $0.29 \mathrm{mg} / \mathrm{L}$. Excessive intake of $\mathrm{Pb}$ can damage nervous system and cause brain disorder. Previous studies have shown maximum levels of $\mathrm{Pb}$ in groundwater to be $0.026 \mathrm{mg} / \mathrm{L}$ (Kortatsi 2004) and maximum levels of $\mathrm{Pb}$ in surface water to be $<0.05 \mathrm{mg} / \mathrm{L}$ (Kuma 2004).

Mean nickel levels were higher than the WHO guideline of $0.02 \mathrm{mg} / \mathrm{L}$ far all the sampling sites in all the communities studied. Previous studies have shown maximum levels of $\mathrm{Ni}$ in groundwater to be $0.076 \mathrm{mg} / \mathrm{L}$ (Kortatsi 2004). Levels of zinc in water samples were all below the WHO maximum limit of $5.00 \mathrm{mg} / \mathrm{L}$.

Mean cadmium levels in the water samples were above the WHO guideline of $0.005 \mathrm{mg} / \mathrm{L}$. These values are comparable with results obtained in previous studies which showed maximum levels in surface water to be $<0.05 \mathrm{mg} / \mathrm{L}$ (Kuma 2004) and maximum levels in groundwater to be $0.003 \mathrm{mg} / \mathrm{L}$ (Kortatsi 2004). Cadmium concentrations in unpolluted natural waters are usually below $1 \mu \mathrm{g} / \mathrm{L}$.

The sampling sites within Wamase and the Pompora Pump Station, exhibited significant mean levels of arsenic in water which were above the WHO value of $0.01 \mathrm{mg} / \mathrm{L}$. The presence of arsenic in natural water is related to the process of leaching from the arsenic containing rocks and ores (Nordstrom 2002). Arsenic is a primary constituent of certain ores and occur as a trace impurity in others (Lorenzen et al. 1995). Adverse effects of arsenic have been reported to be dependent strongly on the dose and duration of exposure (Mukherjee et al. 2006). Asante et al. (2007) have reported that concentrations of arsenic in human urine increased significantly with those in water, implicating drinking water as the source of arsenic in humans. Previous studies show maximum levels in groundwater to be $0.046 \mathrm{mg} / \mathrm{L}$ (Kortatsi 2004) and maximum levels in surface water to be $0.137 \mathrm{mg} / \mathrm{L}$ (Kuma 2004). 


\section{Correlation analysis for different water quality parameters} Correlation is a method used to evaluate the degree of interrelation and association between two variables (Nair et al. 2005). A correlation of +1 indicates a perfect positive relationship between two variables. A correlation of -1 indicates that one variable changes inversely with relation to the other. A correlation of zero indicates that there is no relationship between the two variables (Kapil et al. 2009). The correlation study was carried out to find the plausible associations of the selected metals and anions in water from the Jimi River and its tributaries (Table 5). Strong positive association was observed between $\mathrm{pH}-\mathrm{Ni}$ and $\mathrm{Zn}-\mathrm{Fe}$ with $\mathrm{r}$ values of 0.992 and 0.905 , respectively. There were also positive correlation between $\mathrm{Fe}-\mathrm{S}^{2-}, \mathrm{Fe}-\mathrm{NO}_{3}{ }^{-} \mathrm{Fe}-\mathrm{NO}_{2}{ }^{-}$with $\mathrm{r}$ values of $0.910,0.978$ and 0.990 , respectively at 0.01 significant levels. Similarly there were $\mathrm{Zn}-\mathrm{S}^{2-}$ correlation with $\mathrm{r}$ value of 0.801 at 0.05 significant value and, $\mathrm{Zn}-\mathrm{NO}_{3}{ }^{-}$and $\mathrm{Zn}-\mathrm{NO}_{2}{ }^{-}$correlations with $\mathrm{r}$ values of 0.940 and 0.945 , respectively at 0.01 significant levels for water samples. Inter-ion correlations were also observed for $\mathrm{S}^{2-}-\mathrm{NO}_{3}{ }^{-}$, $\mathrm{S}^{2-}-\mathrm{NO}_{2}{ }^{-}$and $\mathrm{NO}_{3}{ }^{-}-\mathrm{NO}_{2}{ }^{-}$with $\mathrm{r}$ values of $0.937,0.926$ and 0.992 , respectively for water samples. It demonstrated that the metals and ions showing strong mutual associations were likely to be contributed by the same source, while those showing negative associations were found to have opposite distributions.

\section{Principal component analysis (PCA)}

By principal component analysis, complex linear correlation between heavy metal concentrations in surface was determined, which enabled interpretation of correlation of elements in the study area. Elements belonging to a given component were defined by factor matrix after varimax rotation, with those having strong correlations grouped into components. The identification of component is based on dominant influence. The distribution manner of individual association of element in surface and groundwater was determined by principal component method. Principal component analysis (PCA) reduces the multidimensionality of data set by a linear combination of original data to generate new latent variables which are orthogonal and uncorrelated to each other. The principal components (PCs) resulting from PCA are sometimes not readily interpreted and varimax rotation with Kaiser normalization is executed to reduce the dimensionality of the data, identify most significant variables and infer the processes that control water chemistry. Varimax factor loading coefficient with a correlation of: $>0.75$ are explained as strong significant factor loading (FL); $0.75-0.50$ are considered as moderate FL; and $0.50-0.30$ are considered as weak FL.
As shown in Table 6, three components with eigenvalues greater than 1 that explained $95 \%$ of the total variance of the data were obtained. Principal component 1 (PC1) accounted for $48.65 \%$ of the total variance, had high loadings of $(>0.76)$ for $\mathrm{Ca}, \mathrm{HCO}_{3}{ }^{-}, \mathrm{NO}_{3}{ }^{-}, \mathrm{NO}_{2}{ }^{-}, \mathrm{Fe}, \mathrm{Zn}$ and $\mathrm{Pb}$ and moderate loadings for $\mathrm{Ni} \mathrm{S}_{2}{ }^{-}, \mathrm{Mg}^{+}$, and $\mathrm{SO}_{4}{ }^{2-}$. The strong negative loadings on $\mathrm{CN}^{-}$indicate an inverse relation with $\mathrm{Ca}, \mathrm{HCO}_{3}{ }^{-}, \mathrm{NO}_{3}{ }^{-}, \mathrm{NO}_{2}{ }^{-}, \mathrm{Fe}, \mathrm{Zn}$ and $\mathrm{Pb}$. Based on principal component analysis on surface water PC1 is interpreted to represent the influence of mining activity on the levels of these heavy metals in the study area. Therefore, the source of pollution is both natural and anthropogenic. PC2 which accounted for $37.8 \%$ of the total variance exhibited high loadings of $\mathrm{Zn}, \mathrm{Fe}$, and $\mathrm{Pb}$ and moderate loading of $\mathrm{NO}_{2}{ }^{-}$. PC3 which accounted for $8.78 \%$ of the total variance displayed a high loading for $\mathrm{Cd}$. Based on principal component analysis on surface water PC3 is interpreted to represent Cadmium contaminated surface water. This source of contamination is largely anthropogenic. Effluents from extractive industries established over the last half century within the study area are directly discharged onto surrounding land and surface water bodies (Obiri 2007). The discharge of effluents into surface and groundwater constitute non-point sources of contamination. Cadmium is usually present in all soils and rocks. It occurs naturally in zinc, lead, and copper ores, in coal, and other fossil fuels and shales (Weiner 2000).

\section{Health risk assessment}

The health risk associated with drinking water depends on the volume of water consumed and the weight of the individual. The study showed that individuals that consumed water from the Jimi river and its tributaries containing $\mathrm{As}, \mathrm{Cd}, \mathrm{Fe}, \mathrm{Ni}, \mathrm{Zn}$ and $\mathrm{Pb}$ had hazard quotient $\left(\mathrm{HQ}_{\mathrm{ing}}\right)$ values for both adults and children were found to be less than unity (Table 7 ) suggesting no potential adverse effects on local residence. Similarly the hazard quotient through the dermal route $\left(\mathrm{HQ}_{\text {dermal }}\right)$ for $\mathrm{Cd}, \mathrm{Fe}$, $\mathrm{Ni}, \mathrm{Zn}$ and $\mathrm{Pb}$ was found to be less than unity for both adults and children indicating that the dermal adsorption of these metals in the Jimi River and its tributaries may have little or no health threat. $\mathrm{HI}_{\text {dermal }}$ values are also below the safe limit of unity, which clearly indicates that there was no cumulative potential of adverse health risks in water samples via direct ingestion or dermal ingestion to the inhabitants of the drinking water source.

\section{Conclusions}

This study revealed considerable chemical contamination of the Jimi River and its tributaries through geologic processes, gold mining operations and other anthropogenic sources. The work also established high 


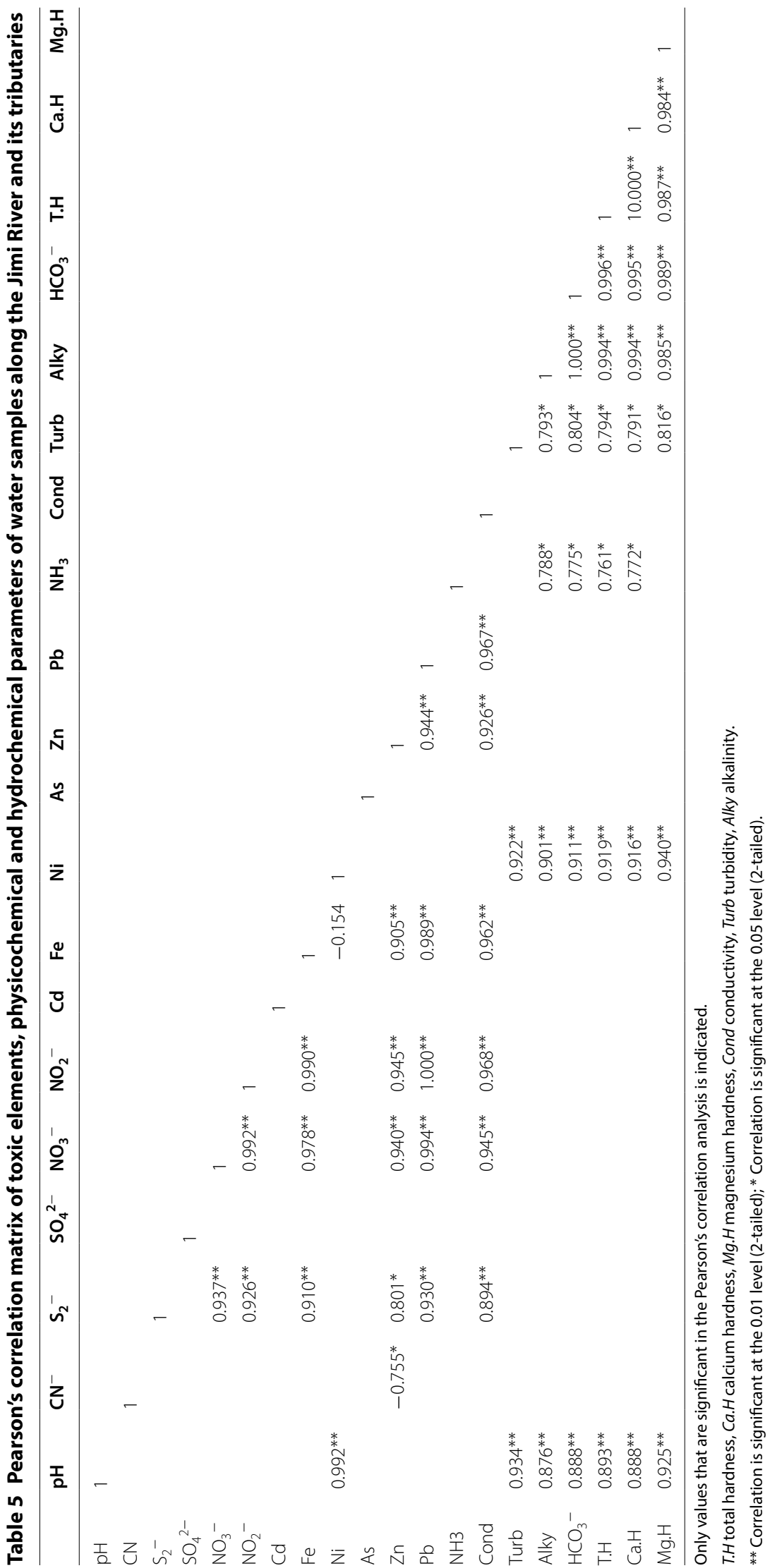


Table 6 Varimax rotated factor loadings and communities of three experimental variables in R-mode

\begin{tabular}{|c|c|c|c|c|c|}
\hline & \multicolumn{3}{|c|}{ Component } & \multicolumn{2}{|c|}{ Communalities } \\
\hline & PC1 & PC2 & $\mathrm{PC} 3$ & Initial & Extraction \\
\hline $\mathrm{HCO}_{3}^{-}$ & 0.759 & -0.649 & 0.051 & 1.000 & 0.998 \\
\hline Alk & 0.774 & -0.632 & 0.037 & 1.000 & 0.991 \\
\hline $\mathrm{pH}$ & 0.386 & -0.907 & 0.139 & 1.000 & 0.994 \\
\hline $\mathrm{Ca}^{2+}$ & 0.754 & -0.640 & 0.129 & 1.000 & 0.941 \\
\hline $\mathrm{SO}_{4}^{2-}$ & 0.544 & 0.026 & -0.803 & 1.000 & 0.983 \\
\hline Cond & 0.766 & 0.623 & -0.091 & 1.000 & 0.992 \\
\hline $\mathrm{Mg}^{2+}$ & 0.690 & -0.711 & 0.099 & 1.000 & 0.990 \\
\hline $\mathrm{NO}_{3}^{-}$ & 0.893 & 0.437 & 0.030 & 1.000 & 0.992 \\
\hline $\mathrm{NO}_{2}^{-}$ & 0.835 & 0.543 & 0.013 & 1.000 & 0.820 \\
\hline $\mathrm{Cd}$ & -0.400 & 0.461 & 0.668 & 1.000 & 0.966 \\
\hline $\mathrm{Fe}$ & 0.806 & 0.560 & -0.055 & 1.000 & 0.997 \\
\hline $\mathrm{Ni}$ & 0.430 & -0.890 & 0.141 & 1.000 & 0.915 \\
\hline $\mathrm{Zn}$ & 0.814 & 0.500 & 0.043 & 1.000 & 0.992 \\
\hline $\mathrm{Pb}$ & 0.842 & 0.532 & 0.017 & 1.000 & 0.782 \\
\hline $\mathrm{CN}^{-}$ & -0.568 & -0.384 & -0.558 & 1.000 & 0.959 \\
\hline As & 0.356 & -0.912 & 0.033 & 1.000 & 0.874 \\
\hline $\mathrm{S}_{2}^{-}$ & 0.582 & -0.810 & 0.048 & 1.000 & 0.998 \\
\hline Eigenvalues & 8.270 & 6.423 & 1.491 & & \\
\hline$\%$ of variance & 48.649 & 37.780 & 8.773 & & \\
\hline Cumulative \% & 48.649 & 86.428 & 95.201 & & \\
\hline
\end{tabular}

Table 7 Non-carcinogenic health risk assessment summary for the selected metals in the water for adults and children via ingestion and dermal routes

\begin{tabular}{|c|c|c|c|c|c|c|}
\hline & \multirow[t]{2}{*}{$\mathrm{RfD}_{\text {ing }}(\mu \mathrm{g} / \mathrm{kg} /$ day $)$} & \multirow[t]{2}{*}{$\mathrm{RfD}_{\text {derm }}(\mu \mathrm{g} / \mathrm{kg} /$ day $)$} & \multicolumn{2}{|l|}{ Adults } & \multicolumn{2}{|l|}{ Children } \\
\hline & & & $\mathrm{HQ}_{\mathrm{ing}}$ & $\mathrm{HQ}_{\text {derm }}$ & $H Q_{i n g}$ & $\mathrm{HQ}_{\text {derm }}$ \\
\hline As & 0.3 & & 0.00 to $3.42 \times 10^{-2}$ & - & 0.00 to $1.30 \times 10^{-1}$ & - \\
\hline $\mathrm{Cd}$ & 0.5 & 0.025 & 0.00 to $1.81 \times 10^{-3}$ & 0.00 to $1.72 \times 10^{-4}$ & 0 to $6.90 \times 10^{-3}$ & 0 to $5.06 \times 10^{-4}$ \\
\hline $\mathrm{Fe}$ & 700 & 140 & $2.06 \times 10^{-4}$ to $5.64 \times 10^{-3}$ & $4.88 \times 10^{-6}$ to $1.34 \times 10^{04}$ & $7.86 \times 10^{-4}$ to $2.15 \times 10^{-2}$ & $\begin{array}{c}1.44 \times 10^{-5} \text { to } \\
3.95 \times 10^{-4}\end{array}$ \\
\hline $\mathrm{Ni}$ & 20 & 5.4 & $1.51 \times 10^{-5}$ to $1.24 \times 10^{-2}$ & $1.06 \times 10^{-6}$ to $8.67 \times 10^{-4}$ & $5.75 \times 10^{-5}$ to $4.71 \times 10^{-2}$ & $\begin{array}{c}3.13 \times 10^{-6} \text { to } \\
2.56 \times 10^{-3}\end{array}$ \\
\hline $\mathrm{Zn}$ & 300 & 120 & $3.42 \times 10^{-3}$ to $8.84 \times 10^{-3}$ & $2.43 \times 10^{-6}$ to $6.29 \times 10^{-6}$ & $1.30 \times 10^{-4}$ to $3.38 \times 10^{-4}$ & $\begin{array}{c}7.17 \times 10^{-6} \text { to } \\
1.86 \times 10^{-5}\end{array}$ \\
\hline $\mathrm{Pb}$ & 1.4 & 0.42 & 0 to $6.24 \times 10^{-3}$ & 0.00 to $3.95 \times 10^{-4}$ & 0 to $2.38 \times 10^{-2}$ & 0 to $1.16 \times 10^{-3}$ \\
\hline $\mathrm{HI}_{\text {ing/derm }}$ & - & - & $3.64 \times 10^{-3}$ to $6.03 \times 10^{-2}$ & $8.37 \times 10^{-6}$ to $1.57 \times 10^{-3}$ & $9.74 \times 10^{-4}$ to $2.30 \times 10^{-1}$ & $\begin{array}{c}2.47 \times 10^{-6} \text { to } \\
4.64 \times 10^{-3}\end{array}$ \\
\hline
\end{tabular}

The chronic daily intake (CDI) for As, $\mathrm{Cd}, \mathrm{Fe}, \mathrm{Ni}, \mathrm{Zn}$ and $\mathrm{Pb}$ for both adult and children were observed to be less than 1 (Table 8). Therefore, $\mathrm{CDI}$ indices for heavy metals were found in the order: $\mathrm{Fe}>\mathrm{Zn}>\mathrm{As}>\mathrm{Pb}>\mathrm{Cd}>\mathrm{Ni}$. The CR value was calculated for only As, Cd and Pb because the value of cancer slop for the other could not be assessed in the Integrated Risk Information System (IRIS, provided by USEPA database; USEPA 2005). The CR value for As, Cd and Pb for both adult and children (Table 8 ) were generally found to exceed the safe limit of cancer risk. Generally a CR value greater than 1 in a million ( $\left.10^{-6}\right)$ is considered significant by USEPA.

Table 8 Chronic daily intake (CDI) and carcinogenic risk assessment for the metals in the water samples along the Jimi River and its major tributaries for adults and children via ingestion

\begin{tabular}{|c|c|c|c|c|}
\hline & \multicolumn{2}{|l|}{ Adults } & \multicolumn{2}{|l|}{ Children } \\
\hline & $\mathrm{CDI}_{\text {ing }}$ & $\mathrm{CR}_{\text {ing }}$ & $\mathrm{CDI}_{\text {ing }}$ & $\mathrm{CR}_{\text {ing }}$ \\
\hline As & 0.00 to $1.07 \times 10^{-2}$ & 0.00 to $6.83 \times 10^{-6}$ & 0.00 to $4.08 \times 10^{-2}$ & 0 to $2.61 \times 10^{-5}$ \\
\hline $\mathrm{Cd}$ & 0.00 to $9.43 \times 10^{-4}$ & 0.00 to $1.81 \times 10^{-6}$ & 0.00 to $3.60 \times 10^{-3}$ & 0 to $6.90 \times 10^{-6}$ \\
\hline $\mathrm{Fe}$ & $1.50 \times 10^{-1}$ to 4.12 & - & $5.74 \times 10^{-1}$ to $1.57 \times 10^{1}$ & - \\
\hline $\mathrm{Ni}$ & $3.14 \times 10^{-4}$ to $2.57 \times 10^{-1}$ & - & $1.20 \times 10^{-3}$ to $9.82 \times 10^{-1}$ & - \\
\hline $\mathrm{Zn}$ & $1.07 \times 10^{-2}$ to $2.77 \times 10^{-2}$ & - & $4.04 \times 10^{-2}$ to $1.06 \times 10^{-1}$ & - \\
\hline $\mathrm{Pb}$ & 0 to $9.11 \times 10^{-3}$ & 0.00 to $1.03 \times 10^{-3}$ & 0.00 to $3.48 \times 10^{-2}$ & 0 to $3.93 \times 10^{-3}$ \\
\hline
\end{tabular}


carcinogenic risks $\left(\mathrm{CR}_{\text {ing }}\right)$ for $\mathrm{As}, \mathrm{Cd}$, and $\mathrm{Pb}\left(>10^{-6}\right)$ through the ingestion of surface water from these sources within the communities in the Obuasi Municipality and its environs. These findings make an important contribution to the understanding of the nexus of surface water pollution and its direct implications for public health in the context of a major mining enclave in Ghana. Efforts should therefore be made by local authorities to minimize the risks for these population groups by applying control measures (both technical and non-technical). In addition there is a need for case studies that will deepen our understanding of the level of contamination in water systems, including specific health risks in different exposure groups in most mining areas in Ghana.

\section{Abbreviations \\ CDI: chronic daily intake; AAS: atomic absorption spectrophotometer; RAGS: Risk Assessment Guidance for Superfund; RfD: reference dose; IR: inges- tion rate; EF: exposure frequency; ED: exposure duration; BW: average body weight; AT: is averaging time; SA: exposed skin area; ET: exposure time; CF: unit conversion factor; $\mathrm{HQ}$ : hazard quotient; $C R$ : cancer risk; PCA: principal component analyses; EPA: Environmental Protection Agency; WHO: World Health Organization.}

\section{Authors' contributions}

All authors read and approved the final manuscript.

\section{Acknowledgements}

The authors are grateful to the National Council for Tertiary Education (NTCE), Ghana for a research grant under the Teaching and Learning Innovation Fund (TALIF-KNUSTS/3/005/2005). The assistance provided by the farmers groups in the areas investigated during the sampling period is highly acknowledged. The support of Municipal Chief Executive and the staff of the Obuasi Municipal Assembly deserve mention.

\section{Compliance with ethical guidelines}

\section{Competing interests}

The authors declare that they have no competing interests.

Received: 5 May 2015 Accepted: 16 July 2015

Published online: 30 July 2015

\section{References}

Ackah M, Agyemang O, Anim AK, Osei J, Bentil NO, Kpattah L et al (2011) Assessment of groundwater quality for drinking and irrigation: the case study of Teiman-Oyarifa Community, Ga East Municipality, Ghana. Proc Int Acad Ecol Environ Sci 1(3-4):186-194

Ada FB, Ayotunde O, Ofem BO (2012) Surface and ground water concentration of metal elements in central cross river state, Nigeria and their suitability for fish culture. Int J Environ Sustain 1(2):9-20

Adimado A, Amegbey NA (2003) Incidents of cyanide spillage in Ghana, mineral processing and extractive metallurgy. Trans IMMC 112(2):126-130

Agarwal SK (1999) Studies on the effects of auto exhaust emission on the Mitragna patriflora. Master Thesis, MDS University, Ajmeer, India

Ahmad K, Carboo D (2000) Speciation of As (III) and As (V) in some Ghanaian gold tailings by a simple distillation method. Water Air Soil Pollut 122:317-326

Akabzaa TM, Banoeng-Yakubo BK, Seyire JS (2007) Impact of mining activities on water in the vicinity of the Obuasi mine. West Afr J Appl Ecol 11:101-110
Alsabahi E, Abdulrahmi S, Zuhairi W, Al-Nozaily F, Alshaebi F (2009) The characteristics of leachate and groundwater pollution at municipal solid waste landfill of Ibb City, Yemen. Am J Environ Sci 5(3):256-266

Amasa SK (1975) Arsenic pollution at Obuasi goldmine, town, and surrounding country side. Environ Health Perspect 12:131-135

American Water Works Association (1953) Water quality and treatment. American Water Works Association Inc., New York, p 451

Amonoo-Neizer EH, Nyamah D, Bakiamoh SB (1995) Mercury and arsenic pollution in soil and biological samples around the mining town of Obuasi, Ghana. Water Air Soil Pollut 91:363-373

Anglogold Ashanti (2005) Obuasi Ghana, Country report 2006. Obuasi Municipality (2009). http://www.ghanadistricts.com/districts/?news\&r=2\&_=10. Accessed on 1 April

Asante KA, Agusa T, Subramanian A, Ansa-Asare OD, Biney CA, Tanabe S (2007) Contamination status of arsenic and other trace elements in drinking water and residents from Tarkwa, a mining township in Ghana. Chemosphere 66:1513-1522

Asiam EK (1996) Environmental assessment of gold beneficiation: arsenic audit and impact on the Obuasi environs. Ghana Mining J 2(1):17-20

ATSDR (1993) Toxicological profile of cadmium. US Department of Health and Human Services, Public Health Service, Atlanta

Aucamp P, van Schalkwyk A (2003) Trace element-pollution of soils by abandoned gold-mine tailings near Potchefstroom. S Afr Bull Eng Geol Environ 62:123-134

Ayotunde EO, Offem BO, Ada FB (2011) Heavy metal profile of cross river: cross river state Nigeria using bioindicators. Indian J Anim Res 45(5):232-246

Bamford SA, Osae E, Aboh I, Antwi LA (1990) Environmental impact of the gold mining industry in Ghana. Biol Trace Elem Res 26-27:279-285

Carboo D, Serfor-Armah Y (1997) Arsenic in stream and sediments in Obuasi area. In: Proceeding of the symposium on the mining industry and the environment, KNUST/IDRC, pp 114-119

Chapman D (1992) Water quality assessment, a guide to the use of biota, sediments and water in environmental monitoring. University Press, Cambridge, p 585

Chapman D (1995) Water quality assessment: a guide to the use of biota sediment and water in environmental monitoring. University Press, Cambridge, pp 585-598

Davis DW, Hirdes W, Schaltegger U, Nunoo EA (1994) U-Pb age constraints on deposition and provenance of Birimian and gold-bearing Tarkwaian sediments in Ghana, West Africa. Precambr Res 67:89-107

Eletta O, Adeniyi A, Dolapo A (2010) Physico-chemical characterisation of some ground water supply in a school environment in llorin, Nigeria. Afr J Biotechnol 9(22):3293-3297

EPA (2001) Parameters of water quality: interpretation and standards. Environmental Protection Agency, Ireland, pp 61-62

Essumang DK, Dodoo DK, Obiri S, Yaney JY (2007) Arsenic, cadmium, and mercury in Cocoyam (Xanthosoma sagititolium) and Watercocoyam (Colocasia esculenta) in Tarkwa, a mining community. Bull Environ Contam Toxicol 79:377-379

Essumang DK, Senu J, Fianko J, Nyarko B, Adokoh C, Boamponsem L (2011) Groundwater quality assessment: a physicochemical properties of drinking water in a rural setting of developing countries. Can J Sci Ind Res 2(3):102-126

Fuggle RF, Rabie MA (1994) Environmental management in South Africa. Juta, Cape Town

Golow AA, Schlueter A, Amihere-Mensah S, Granson HLK, Tetteh MS (1995) Distribution of arsenic and sulphate in the vicinity of Ashanti goldmine at Obuasi, Ghana. Bull Environ Contam Toxicol 56:03-710

Gopalkrushna MH (2011) Assessment of physico-chemical status of ground water samples in Akot city. Res J Chem Sci 1(4):117-124

Hilson G (2002) An overview of land use conflicts in mining communities. Land Use Policy 19(1):65-73

Ishaku JM (2011) Assessment of groundwater quality index for Jimeta-Yola area, Northeastern Nigeria. J Geol Min Res 3(9):219-231

Kapil DM, Mamta K, Sharma DK (2009) Hydrochemical analysis of drinking water quality of Alwar District Rajasthan. Nat Sci 7(2):30-39

Kori-Siakpere D, Ubogu E (2008) Sub lethal hematological effects of zinc on the fresh water fish. Heteroclarias Sp. (Osteichthyes: Claridae). Afr J Biotechnol 7(12):2068-2073 
Kortatsi BK (2004) Hydrochemistry of groundwater in the mining area of Tarwa-Prestea, Ghana. PhD thesis, University of Ghana, Legon-Accra, Ghana

Kuma JS (2004) Is groundwater in the Tarkwa gold mining district of Ghana potable? Environ Geol 45:391-400

Kuma JS, Younger PL (2004) Water quality trends in the Tarkwa gold-mining district, Ghana. Bull Eng Geol Environ 63:119-132

Kumar J, Pal A (2012) Water quality monitoring of Ken River of Banda District, Uttar Pradesh, India. Elixir Pollut 42:6360-6364

Kumi-Boateng B (2007) Assessing the spatial distribution of arsenic concentration from goldmine for environmental management at Obuasi, Ghana. M.Sc. thesis. Int. Institute for Geo-Info. Sci. Earth Observation, Enschede, The Netherlands

Lee CH (2003) Assessment of contamination load on water, soil and sediment affected by the Kongjujeil mine drainage, Republic of Korea. Environ Geol 44:501-515

Li SY, Zhang QF (2010) Spatial characterization of dissolved trace elements and heavy metals in the upper Han River (China) using multivariate statistical techniques. J Hazard Mater 176(1-3):579

Liang F, Yang S, Sun C (2011) Primary health risk analysis of metals in surface water of Taihu Lake, China. Bull Environ Contamin Toxicol 87(4):404-408

Longe E, Balogun M (2010) Groundwater quality assessment near a municipal landfill, Lagos, Nigeria. Res J Appl Sci Eng Technol 2(1):39-44

Lorenzen I, van Deventer JSJ, Landi WM (1995) Factors affecting the mechanism of the absorption of arsenic species on activated carbon. Min Eng 8:557-569

Mahananda M, Mohanty B, Behera N (2010) Physico-chemical analysis of surface and ground water of Bargarh District, Orissa, India. Int J Res Rev Appl Sci 2(3):284-295

Manu A, Twumasi YA, Coleman TL (2004) Application of remote sensing and GIS technologies to assess the impact of surface mining at Tarkwa, Ghana. Geoscience and remote sensing symposium IGARSS Proceedings. IEEE International, vol 1, pp 572-574

Miller GT (1999) Environmental science: working with the earth, 7th edn. Wadsworth, Belmont

Mukherjee A, Sergupta MK, Ahamed S, Das B, Nayak B, Lodh D et al (2006) Arsenic contamination in ground water, a global perspective with emphasis on the Asian scenario. J Health Popul Natr 24:142-163

Nair GA, Mohamed Al, Premkumar K (2005) Physico-chemical parameters and correlation coefficients of ground waters of North-East Libya. Pollut Res 24(1):1-6

Nkansah MA, Ephraim JH (2009) Physicochemical studies of water from selected boreholes in the Bosomtwi Atwima-Kwanwoma district of Ghana. Pacific J Sci Tech 10(2):643-648

Nkansah MA, Boadi MO, Badu M (2010) Assessment of the quality of water from hand-dug wells in Ghana. Environ Health Insights 4:7-12

Nordstrom DK (2002) Worldwide occurrences of arsenic in ground water. Science 296:2143-2145

Obiri S (2007) Determination of heavy metals in boreholes in Dumasi in the Wassa west district of western region of the Republic of Ghana. Environ Monit Assess 130:455-463

Okeola FO, Kolawole OD, Ameen OM (2010) Comparative study of physicchemical parameters of water from a River and its surrounding wells for possible interactive effect. Adv Environ Biol 4(3):336-344

Putz J (2003) Chemical analysis of drinking water for India-Canada environment. http://www.docstoc.com/docs/.../Chemical-analysis-of-drinkingwater. Accessed 23 Jan 2015

Ramachandra TV, Solanki M (2007) Ecological assessment of lentic water bodies of Bangalore. ENVIS Tech Rep 25:1-105

Sayyed MRG, Wagh GS (2011) An assessment of groundwater quality for agricultural use: a case study from solid waste disposal site SE of Pune, India. Proc Int Acad Ecol Environ Sci 1(3-4):195-201
Schafer Al, Rossiter HMA, Owusu PA, Richard BS, Awuah E (2010) Developing country water supplies: physico-chemical water quality in Ghana. Desalination 251:193-203

Smedley PL (1996) Arsenic in rural groundwater in Ghana. J Afr Earth Sci 22:459-470

Smedley PL, Edmunds WM, Pelig-Ba KB (1996) Mobility of arsenic in ground water in the Obuasi area of Ghana. In: Appleton JD, Fuge R, McCall GJH (eds) Environ. Geochem. Health, vol 113. Geol Soc Special Publication, pp 163-181

Tay CK (2008) Chemical characteristics of groundwater in the Akatsi and Ketu Districts of the Volta Region, Ghana. CSIR-Water Research Institute, P. O. Box AH 38, Achimota-Accra, Ghana

Tay C, Kortatsi B (2007) Groundwater quality studies: a case study of Densu Basin, Ghana. West Afr J Appl Ecol 12:81-99

Tiwari RN (2011) Assessment of groundwater quality and pollution potential of Jawa Block Rewa District, Madhya Pradesh, India. Proc Int Acad Ecol Environ Sci 1(3-4):202-212

USEPA (1989) Risk assessment guidance for superfund, vol 1, Human health evaluation manual (part A), report EPA/540/1-89/002, United States Environmental Protection Agency, Washington, DC, USA

USEPA (1994) Design and evaluation of tailings dams', technical reportEPA530-R-94-038. USEPA, Office of Solid Waste, Special Waste Branch, Washington, DC

USEPA (1997) The incidence and severity of sediment contamination in surface waters of the United States: volume 1: National Sediment Quality Survey. EPA/823/R-97/006. Washington, District of Columbia

USEPA (2005) Guidelines for carcinogenic risk assessment. Risk assessment forum, Washington, DC, USA EPA/630/P-03/001F

U.S. Geological Survey (USGS) (1999) Contaminated sediments database development and assessment in Boston harbor. U.S. Department of the Interior. U.S. Geological Survey fact Sheet 078-99

Weiner ER (2000) Applications of environmental chemistry: a practical guide for environmental professionals. CRC Press, Florida

World Health Organization (2007) Chemical safety of drinking water: assessing priorities for risk management. WHO, Geneva

Wu B, Zhao DY, Jia HY, Zhang Y, Zhang XX, Cheng SP (2009) Preliminary risk assessment of trace metal pollution in surface water from Yangtze River in Nanjing section, China. Bull Environ Contamin Toxicol 82(4):405-409

Yankey RK, Akiti TT, Osae S, Fianko JR, Duncan AE, Amartey EO et al (2011) The hydrochemical characteristics of groundwater in the Tarkwa mining area, Ghana. Res J Environ Earth Sci 3(5):600-607

Yidana SM, Duke Ophori D, Banoeng-Yakubo B (2007) A multivariate statistical analysis of surface water chemistry data, the Ankobra basin, Ghana. J Environ Manag 86:80-87

Yu FC, Fang GH, Ru XW (2010) Eutrophication, health risk assessment and spatial analysis of water quality in Gucheng Lake, China. Environ Earth Sci 59(8):1741-1748

Zhang C (2007) Fundamental of environmental sampling and analysis. Wiley, New York, p 109

\section{Submit your manuscript to a SpringerOpen ${ }^{\odot}$ journal and benefit from:}

- Convenient online submission

$\checkmark$ Rigorous peer review

- Immediate publication on acceptance

- Open access: articles freely available online

- High visibility within the field

- Retaining the copyright to your article

Submit your next manuscript at springeropen.com 